form an unusually elegant means of studying these complexes. When a second substance is injected into the aqueous solution underlying a monolayer of a pure substance, a large increase in surface pressure is found if complex formation occurs accompanied by penetration of the second molecular species into the monolayer. If the reaction is between polar groups only of the two molecular species, there may be no change of surface pressure, but there will be a change in the electrical potential across the film. If there is no complex formation of any type, no change in either surface pressure or potential occurs. Complex formation of the type revealed by these surface techniques has been shown to be of importance in the mechanism of red cell lysis, and in the permeation of some membranes by such substances as phenols. For example, the penetration of hexyl resorcinol into Ascaris lumbricoides, according to Trim and Alexander, may be accelerated by a factor of about fourfold by adding low concentrations of detergents, with which the resorcinol forms complexes. The mechanism of this acceleration is not yet understood, and may well repay detailed study.

Interesting complexes are formed between some carotenoids and certain proteins. Astaxanthin exists in the eggs and integument of lobsters, crabs, etc., as a blue-green pigment. The carotenoid is readily oxidized to astacene in the dead animals. When the association between carotenoid and specific protein breaks down, a colour-change ensues. The association may be destroyed by boiling, which denatures the specific protein, or by addition of sodium soaps. In the latter case, the change is reversible, restoration of the original complex being achieved by addition of calcium (Peters and Wakelin). Visual purple also appears to be a complex of this type, namely, protein-carotenoid. One theory of the action of light upon visual purple is that it oxidizes a terminal $\mathrm{CHOH}$ group of a polyene chain to the corresponding aldehyde. Monolayer studies show that on conversion of a $\mathrm{CHOH}$ group to a $\mathrm{CO}$ group, a large change of surface potential occurs. It is therefore possible that, if the carotenoid of visual purple also forms part of the lipoid layer of the cell membrane, the photo-oxidation will produce a change in surface potential sufficient to cause electrical excitation of the cell. These relationships are at present all highly speculative, but it is in harmony with recent developments in cell physiology to adopt the working hypothesis that the stimulation of retinal cells by light is produced by a surface photo-oxidation of the visual pigment incorporated in the cell membrane, and that the change in surface potential produced by this reaction temporarily discharges the resting potential of the cell, causing an electrical response.

These reflexions on the topics of Prof. Rideal's lecture show that a pathway for investigation of many biological problems has already been secured by the study of reactions at interfaces. So numerous are these possibilities that the rate of investigation of these fields is likely in the immediate future to be determined almost entirely by the number of investigators available; all such investigators will find a source of inspiration in Prof. Rideal's lecture.

\title{
OBITUARIES
}

\section{Prof. Ernest Shearer}

A Natrve of the island of Stromness in Orkney, Ernest Shearer was brought up to farming; but he could also sail a boat and follow the maritime pursuits of his Viking ancestry. A 'lad of parts', he was thoroughly schooled in mathematics and classics and went on to the University of Edinburgh where, between 1897 and 1904, he studied and graduated M.A. with honours in economics and B.Sc. in agriculture. His first appointment was to the Indian Agricultural Service, where in five years he reached the grade of assistant inspector-general. In 1911 he was appointed under the Egyptian Government as principal of the Giza Higher College of Agriculture and in 1919 he was made chief technical officer in the Egyptian Ministry of Agriculture.

In 1924 Shearer accepted the post of principal in the Edinburgh and East of Scotland Agricultural College ; two years later he was made professor of agriculture in the University, thus becoming the first head of the Edinburgh School of Agriculture. During his tenure of office the proper utilization of land and the teaching of young farmers becarne more and more of national importance, and he rose to eminence as an authority on agricultural education. He reached this position by reason of his training and experience, but also because of inclination, for he had a great interest in, and sympathy for, young people. When he retired from his academic posts in the autumn of 1944 he became secretary to the Mid and East Lothian Agricultural Executive Committees, and thus continued to serve the farming community until the time of his death.
Shearer was a large and genial man, entirely free from affectation, with a strong sense of humour and great personal charm. Completely at ease in any situation, he would pass an hour as happily with his gardener as with his fellows on the Senate. He handled a brilliant pen and possessed great strength of character and determination. Not only was he thus well qualified for leadership but he could also be relied on to fight for any right cause and to stand like a bulwark in the interests of his people.

His hobby was the propagation of fine fruits and beautiful flowers. He had planned to retire to his beloved Orkney and to devote himself to the production of plants which would bring both amenities and profit to the island farmers. His untimely death is, therefore, as much a loss to his native land as it is a grievous blow to his friends and colleagues.

\section{J. A. MorE.}

\section{Mr. L. E. Adams}

LIONEL ERnest Adams, who was well known to an earlier generation as an active and enthusiastic observer of the natural history of the British Isles, died at Ryde, Isle of Wight, on September 20, at the age of ninety.

Adams was the nephew of Henry and Arthur Adams, famous in their day for their researches on the molluses, and joint authors of "The Genera of Recent Mollusca". Circumstances did not allow him to follow his uncles' wider sweep, and he had to confine himself to the British land and freshwater species, on which he became an authority of repute. 
In 1884 he published "The Collectors' Manual of British Land and Freshwater Shells" with coloured plates drawn by his brother Gerald, but the figures of Pupa and Vertigo (P1. vii, Figs. 10-22) prove that the author himself was no mean artist; a second edition appeared in 1896. Apart from this one book, Adams published many notes and papers in various natural history journals, especially in the Journal of Conchology. Most of these dealt with the habits of the animals, and were precursors of the ecological studies so fashionable to-day.

The native mammals of Britain attracted him strongly, and on them he spent much of his energy. The most widely known of these researches is that on the 'fortress' of the m)le. After digging out no fewer than three hundred of these structures, Adams was able to show that not one of them was like the familiar figure derived from Blasius and Geoffroy St. Hilaire, which had been copied by one or another writer of popular works for more than a hundred years.
Even this did not exhaust Adams's activities. There was scarcely a group of invertebrates from earthworms to woodlice which he did not collect at some time or other, either on his own behalf or because he knew that someone needed the material for study. In the field he was a lively companion, a noted teller of stories; as a correspondent he was prompt and accurate, ready to pass on all the information at his disposal.

A. T. HopwOOD.

WE regret to announce the following deaths:

Prof. George R. Gage, professor of botany in Vanderbilt University, Nashville, Tennessee, on August 18, aged fifty-five.

Mr. C. F. Dendy Marshall, a founder member and past-president of the Newcomen Society and an authority on the early history of railways, on June 14, aged seventy-two.

\section{NEWS and VIEWS}

\section{Biochemistry at University College, London: Prof. John Yudkin}

Prof. F. G. Young

Prof. F. G. Young is relinquishing his chair at St. Thomas's Hospital Medical School to succeed Sir Jack Drummond as professor of biochemistry at University College, London. In so doing, Prof. Young will be renewing a long association with University College, of which he was an undergraduate in the honours school of chemistry ; for, in addition to receiving his early training there, he was successively (1929-32) Bayliss-Starling Scholar in biochemistry, Sharpey Scholar and Shafer Prizeman in physiology. After holding Beit Memorial fellowships for medical research, Prof. Young then gained further experience by serving as honorary research assistant in the Department of Physiology, Aberdeen, and research associate, Department of Physiology, Toronto, returning to University College in 1934 as honorary assistant in the Department of Biochemistry. Two years later he joined the scientific staff of the Medical Research Council, on which he stayed until his appointment to the chair at St. Thomas's Hospital Medical School in 1942.

Prof. Young has already established an international reputation for himself by his research work. Commencing with the intermediary metabolism of carbohydrates, he was led naturally to the study of the diabetogenic action of extracts of the anterior pituitary and later to other activities of this gland. With Folley he published an important contribution upon the lactogenic hormone which led to further studies with Folley and others on the galactopoietic action of pituitary extracts. It is, however, in the sphere of carbohydrate metabolism that Prof. Young's chief interest has resided and in which his most numerous contributions have been made. In addition to his great activity as a research worker, Prof. Young has also given generously of his time to the Biochemical Society, which he served as joint secretary during 1938-42. In this year he was elected chairman of the editorial board of the Biochemical Journal, and the high standard maintained by that journal is an eloquent tribute to the success of his vigorous leadership. Prof. Young will carry the good wishes of all his colleagues with him to University College.
DR. JoHN YUDKIN, whose appointment to the chair of physiology at King's College of Household and Social Science (University of London) has recently been announced, takes with him from Cambridge a high reputation as an experienced and successful toacher. Since 1934 he has been supervisor in biochemistry and physiology at Christ's and Emmanuel Colleges, and sinco 1940 director of medical studies at Christ's. He is also distinguished as an investigator with wide interests in several fields of biochemistry and nutrition. Possessing a particular regard for the social implications of nutritional knowledge and its application in public health, he has shown much organizing ability in the planning of various nutritional and dietary surveys. Dr. Yudkin entered Christ's College with an open scholarship in 1929 and graduated in 1931, after taking biochemistry in Part 2 of the Natural Sciences Tripos. He was awarded the Benn Levy Research Studentship in 1933, and for some years was engaged in research at the School of Biochemistry and the Department of Colloid Science, Cambridge, on problems relating to bacterial enzymes, with special reference to the mechanism of adaptation and variation. In 1936 he interrupted his research work temporarily in order to complete his medical qualification; he received the Letheby Prize in pathology at the London Hospital.

Since 1936 Dr. Yudkin has specialized in nutritional investigations, and has been attached to the Dunn Nutritional Laboratory, Cambridge, where he has held successively a Grocers' Scholarship and a Halley Stewart Fellowship. $\mathrm{He}$ is author, or part author, of some twenty publications on the subject: the topics in which he has been specially interested including, inter alia, vitamin $\mathrm{B}_{1}$ metabolism ; dark adaptation and slit-lamp microscopy; dietary and nutritional surveys on school children and factory workers; and feeding tests with vitamins and other supplements. $\mathrm{He}_{0}$ joined the R.A.M.C. in 1943, being first attached to the R.A.M.C. College in London, and later as pathologist to the West African Forces, Sierra Leone, and has published a number of papers from both these centres. 